\title{
Effects of Financial Performance and Governance on Corporate Social Responsibility Disclosure: Evidence from Islamic Financial Institutions in Malaysia
}

\author{
Haslinda Yusoff (Corresponding author) \\ Faculty of Accountancy, Universiti Teknologi MARA, 40450 Shah Alam, Selangor, Malaysia \\ Tel: +603-55443490 Email: hasli229@salam.uitm.edu.my \\ Nor Khadijah Mohd Azhari \\ Social Sciences Institute, Eskisehir Osmangazi University, Turkeye \\ Tel: +905-531542024 Email: dijah4041@gmail.com \\ Faizah Darus \\ Accounting Research Institute, Universiti Teknologi MARA, 40450 Shah Alam, Selangor, \\ Malaysia \\ Tel: +603-55444996 Email: faiza634@salam.uitm.edu.my
}

\begin{abstract}
Islamic financial institutions (IFIs) are established based on Islamic foundations and their corporate practices are expected to be aligned with Islamic laws and framework. This study seeks to understand the determinants for the CSR disclosure of IFIs in Malaysia. Using the 2010 annual reports of 37 IFIs, this study investigates the effects of financial performance and corporate governance mechanism (proxied by Shariah supervisory committee or SCC and ownership structure) on CSR disclosure. Results reveal that between financial performance and SCC and ownership structure, only the latter significantly influences CSR disclosure. Overall, the findings offer insights into current reporting practices and propose ideas pertaining to the establishment of an Islamic-based CSR reporting framework. The significant factors influencing CSR disclosure may be used to develop effective practice among IFIs in Malaysia and other countries.
\end{abstract}

Keywords: Corporate Social Responsibility; Disclosure Practice; Financial Institution; Shariah; Corporate Governance

\section{Introduction}

The global Islamic capital market (ICM) has experienced a phenomenal growth in recent years through the introduction of products, infrastructures, institutions, and intermediaries in supporting the continuous development of the market. The Investors Offshore Editorial Team Report (August 2010) indicates that the Shariahcompliant investable wealth pool grew by $20 \%$, achieving a cumulative total of USD 480 billion in 2009 compared to USD 400 billion in 2008. This figure encompasses a global count of 628 Islamic financial institutions (IFIs) by the end of 2009 (Lee and Menon, 2010; Said, 2010). The City UK estimated the recent achievement of the global market for Islamic financial services, as measured by Shariah compliant assets, and the record reached USD 1.688 trillion in 2013 (United Kingdom Islamic Finance Secretariat, 2013) (Elsarg, 2014, p. 4). Malaysia and Saudi Arabia represent the two largest Islamic funds, with a combined total Islamic fund of assets under management worth USD 46.5 billion, accounting for $63 \%$ of the total industry as of December 2013. The development of the Islamic economic market in Malaysia reflects the country's well-publicized commitment to eventually emerge as the global frontrunner in ICM. Such progression is in line with Malaysia's 
mission to become the world's premier halal hub, which will offer a comprehensive range of halal products and services.

ICM is a parallel market to the conventional capital market; it complements the Islamic banking system in expanding the Islamic financial markets in Malaysia. Consequently, Bank Negara Malaysia took the initiative to enhance Islamic financial governance by introducing the Shariah Governance Framework in 2011, with the primary objective of ensuring that operations and business activities of IFIs in Malaysia are in accordance with the Islamic (Shariah) principles. To ensure overall compliance with Shariah, a specific regulatory body for Shariah compliance at the Central Bank is established, i.e., the Shariah Advisory Council, and each IFI has its own Shariah supervisory committee (SSC). Haniffa (2002) argues that apart from supporting good governance, ICM is crucial for spearheading the direction of Islamic social reporting and thus essential for fulfilling religious obligations. Fundamentally, IFIs are expected to uphold Islam in a holistic manner for all of their management and operational obligations, including corporate social responsibility (CSR) duties.

The aim of this study is twofold, that is, to examine the CSR disclosure (CSRD) of IFIs based on Shariah principles and to investigate the potential determinants that advance such disclosure. The prevailing literature on corporate reporting suggests that CSRD is primarily influenced by various factors, including those related to financial performance (e.g., Ghani \& Said, 2010; Masruki et al., 2010; Lungu et al., 2011; Malin et al., 2014), SSC establishment (e.g., Karim, 1995; Hameed, 2009; Farook, et al., 2011), ownership structure (e.g., Archer et al., 1998; Farook et al., 2011), governance characteristics (e.g., Said et al., 2009), and company size (e.g., Othman et al., 2009; Masruki et al., 2010). These findings consequently call for the investigation of the exclusive role of IFIs in an Islamic-based CSR reporting environment as opposed to the conventional secular-based one. The practical implementation of IFIs is hoped to be in line with the tenets and teachings of the Shariah (Abdul Azeez, 2012).

The following section provides a brief review of the literature on CSR from an Islamic perspective as well as the underpinning Islamic principles for the study. The subsequent section discusses the research methodology. The next section presents the findings of the study, and the final section concludes the study, highlighting key findings and their contributions as well as future research directions.

\section{Literature Review}

\section{CSR from an Islamic Perspective}

In Islam, humankind is the representative of Allah, the Creator, and as the representative, humankind must take care of Allah's creations. Islam is not merely a religion but more importantly a way of life. The Qur'an and Sunnah govern the life of Muslims and guide their daily activities, including their business enterprises. As Prophet Mohammed (SAW) explained:

"I will be the foe to three persons on the day of judgment, one of them being the one who, when he employs a person that has accomplished his duty, does not give him his due."

\section{(Hadith narrated by Sahih Bukhari)}

In the context of Islam and CSR, Aribi and Gao (2010) highlight that many existing Islamic business values are essentially consequences of CSR activities. Farook (2007) and Basah and Yusuf (2013) state that the core basis of CSR from an Islamic perspective derives itself from principles, as revealed in the Qur'an. The three major fundamental principles include the vicegerent role of humankind on Earth (as a khalifah), divine accountability, and the obligation to encourage good and forbid evil. These principles involve fundamental areas in 
which humans must be responsible. As Allah says:

\section{"The believing men and believing women are allies of one another. They enjoin what is right and forbid what is wrong and establish prayer and give zakah and obey Allah and His Messenger. Those - Allah will have mercy upon them. Indeed, Allah is exalted in Might and Wise."}

(Al Quran 9:71)

These essentials denote the wider concept of accountability for CSR. The principle of vicegerency indicates that as the representative of Allah, humankind has been entrusted with the stewardship of Allah's possessions. This principle also signifies a divine accountability for each Muslim to uphold the values of fairness and justice in his/her daily practices. The verses of the Qur'an imply that every person (khalifah) is individually accountable for their actions in the manner that they have been entrusted with, and for which they will be held accountable on the Day of Judgement, hence the divine accountability. In effect, this Islamic principle motivates a Muslim to carry out his/her social responsibility which should incorporate all aspects of his/her lives. With regard to CSR, Muwazir et al. (2006) emphasize that as a khalifah, each leader in Islamic business organizations is expected to practice CSR. Kamla et al. (2006) further claimed that a leader (i.e., khalifah) must care for the natural environment and other human beings toward increasing virtue and good deeds.

The principle of espousing good and forbidding evil encapsulates the responsibilities that Allah places on human beings as trustees and khalifah. From the Islamic jurisprudence perspective, right refers to what is just or everything that is permissible and recommended, whereas wrong refers to what is unjust or anything that is impermissible and prohibited. Farook (2007) emphasizes that IFIs have a special religious and financial position in society. Moreover, Islamic business ethics in IFIs is mandatory, and they must comply with the Qur'an and Sunnah (Widana et al., 2014). Thus, the IFIs are required to obey the Shariah in all aspects of their operations. Consequently, IFIs have an exemplary role of as religious representatives who embody the interest of the stakeholder while portraying a positive image to the respective stakeholders. Therefore, IFIs should guarantee that their operations are conducted in the permissible or recommended manner and that no aspect of the offensive should enter into their operations.

Through its Standard No. 7, the Accounting and Auditing Organization for Islamic Financial Institutions (AAOIFI, 2010) codified five underlying CSR responsibilities that IFIs should undertake, namely, religious, economic, legal, ethical, and discretionary (refer to Table 1).

Table 1: Underlying CSR Responsibilities of IFIs
\begin{tabular}{|l|l|}
\hline $\begin{array}{l}\text { Underlying } \\
\text { Responsibility }\end{array}$ & Extent of Responsibility/Obligation \\
\hline Religious & $\begin{array}{l}\text { Obey the laws of Islam in all dealings and } \\
\text { operations }\end{array}$ \\
\hline Economic & Be financially viable, profitable, and efficient \\
\hline Legal & $\begin{array}{l}\text { Respect and obey the laws and regulations of } \\
\text { the host country }\end{array}$ \\
\hline Ethical & $\begin{array}{l}\text { Respect the mass of societal, religious, and } \\
\text { customary norms not codified in law }\end{array}$ \\
\hline Discretionary & $\begin{array}{l}\text { Perform a social role in implementing } \\
\text { Islamic ideals over and above the religious, } \\
\text { economic, legal, and ethical responsibilities, } \\
\text { in line with stakeholders' expectations }\end{array}$ \\
\hline
\end{tabular}

Source: AAOIFI (2010)

Regarding AAOFI, Khursid et al. (2014) recently propose a model of Islamic CSR with four key aspects of responsibility and their respective concentrations, as follows:

- Islamic economic responsibility: make profit without harming others

- Islamic legal responsibility: comply with Islamic law

- Islamic ethical responsibility: follow Islamic values

- Islamic philanthropic responsibility: contribute to community 
Drawing on the doctrine of Maqasid al-Shariah and the concept of Maslahah, Darus et al. (2013) propose an Islamic CSR ( $i$-CSR) conceptual framework that will align the CSR policies and practices of Islamic banks with the principles and values of Islam. The study integrates the two conceptions into six CSR dimensions (i.e., strategy, governance, community, workplace, environment, and marketplace) resulting in the prioritization of CSR practices based on Shariah principles. The Islamic fundamental principles (khalifah, divine accountability, and the obligation to promote good and prevent evil), AAOIFI's (2010) underlying CSR responsibilities framework, and the prevailing literature set the platform for understanding CSRD of IFIs, hence laying the theoretical foundation for this study.

\section{Previous Studies}

Numerous studies have explored the CSRD of IFIs (e.g., Maali et al., 2003; Hassan and Harahap, 2010; Aribi and Gao, 2010; Farook et al., 2011). Collectively, they attest that, to a certain degree, CSRD facilitates the enhancement of investors' confidence to invest in the banking and finance industry. Nevertheless, the level of CSRD has yet to improve among business corporations in many countries. Farook et al. (2011) conduct a study on the CSRD of 47 Islamic banks from 14 countries and uncover a low level of practice, i.e., $16.5 \%$ among the Islamic banks globally. Similarly, an earlier study by Maali et al. (2003), which was based on 29 Islamic banks from 16 countries, revealed only $13.3 \%$ of CSRD level of practice.

In addition, a survey of the 2006 annual reports of seven Islamic banks by Hassan and Harahap (2010) found that CSR was not a major priority in their business agenda. However, an inspiring finding from Aribi and Gao (2010), who examined the CSRD of 42 IFIs and conventional financial institutions (CFIs) in 2004, discover that the level of CSRD is greater among the IFIs than among the CFIs. These studies suggest a need to understand the CSRD among IFIs in
Malaysia. How does the Malaysia's CSRD compare to that of other countries as discovered in other studies?

\section{Hypothesis Development}

Previous studies examine the relationship between CSR and financial performance based on a number of theories, including slack resources theory, good management theory, and stakeholder theory (Tsoutsoura, 2004; Mosaid and Boutti, 2012; Fauzi and Idris, 2013; Nor and Hashim, 2014). Buchholtz et al. (1999) claim that slack resource theory is developed based on the belief that a company can conduct its activities because of its resources. Resources required by a company to successfully adapt are slack in nature; any available or free resources, such as financial means and the assets of other organizations, are used to attain the company's specific goal (e.g., Bourgeois, 1981; Jensen, 1986). Slack resources are only available if the enterprise could manage and improve their financial performance. Hence, a company may conduct corporate social-related activities, such as society and community relation, employee relation, and environment performance (Waddock and Grave, 1997). Stakeholder theory is also commonly applied to understand organizations' behavior in providing CSR-related information to various stakeholder groups. Existing literature has shown mixed results on the possible link between CSRD and corporate financial performance (e.g., Siregar and Bachtiar, 2010; Fauzi et al., 2007; Belkaoui and Karpik, 1989).

Janggu (2004) and Othman et al. (2009) discover that companies with higher profits would be more likely to disclose added information, in comparison to those with lower incomes. This outcome arises because the agent (management) is expected to act in the best interest of the principal (shareholders), as the principal unquestionably trusts the agent to run the business to the best of their ability. Nevertheless, from the Islamic perspective, Haniffa (2002) argues that a company is deemed to establish 
a transparent reporting system following the Shariah principles irrespective of whether it is profitable or not. Othman et al. (2009) conduct a study on 56 leading Shariah approved/compliant companies as listed on Bursa Malaysia. They find a positive relationship between profitability and the level of Islamic social reporting. Arguably, with the advantage of access to a greater pool of resources (i.e., financial, facilities, and human capital), larger companies have a higher tendency to report greater extent of CSRDs. On the contrary, Masruki et al. (2010) discover no correlation between the practice and level of profitability upon examining the CSR reporting practices of 18 Islamic banks. They conclude that such a finding arose from the banks' higher dependency on "conventional" business aims. In an attempt to provide further evidence, this study seeks to examine the link between financial performance and CSRD. Accordingly, the potential relationship can be elucidated as follows:

\section{H1: A positive relationship exists between financial performance and CSRD.}

Maali et al. (2003) suggest that given the existence of SSC, the insistence on additional CSRD is unnecessary because compliance with Islamic laws and principles are already assured through their Shariah compliance report. Moreover, if information asymmetry can be reduced through existing monitoring packages (such as the SSC), then a lower need to create additional monitoring for greater CSRD to assure Islamic investors about a bank's commitment to Islamic laws and principles will be present (Ho and Wong, 2001).

Several studies combine corporate governance factors into an index seeking to capture their aggregate effect. Gompers et al. (2001) combined variables as proxies for governance factors to produce a G-Score. Furthermore, a positive relationship is expected between the SSC and the level of CSRD presented by IFIs. Thus, the following hypothesis is formed:

\section{H2: A positive relationship exists between the} SSC and CSRD.

The structure of ownership also determines the level of monitoring and thereby the level of disclosure (e.g., Jensen and Meckling 1976; Ghazali, 2007). Extant literature has explored the effect of ownership structure on voluntary disclosure (e.g., Mitchell et al., 1995; El-Gazzar 1998; Schadewitz and Blevins, 1998; Eng and Mak 2003). Farook et al. (2011) espouse that Islamic investors are capable of influencing the level of compliance with Islamic principles, resulting in an increased level of CSRD. In the context of IFIs, Islamic investors are more likely to invest their funds as investment account holders (IAHs) rather than as shareholders as they are primarily interested in the services offered by IFIs. Furthermore, investment accounts with IFIs are generally more accessible than shares of IFIs. Therefore, IAHs are expected to express greater interest in ensuring that IFIs' operations are in compliance with Shariah and would drive the IFIs toward delivering their commitments of social responsibility. As such, the influence of IAHs will determine the level of compliance of IFIs to Shariah and, consequently, the level of CSRD presented by the IFIs. This suggests that CSRD is positively related to the size of IAH funds as a proportion of the shareholders' funds. These findings provide the basis for this study to examine the possible correlation between ownership structure and CSRD.

\section{H3: A positive relationship exists between ownership structure and CSRD.}

Figure 1 describes the conceptual framework of this study. This study investigates the relationship between the CSRD for IFIs and three identified determinants based on the Shariah fundamental principles. 
Shariah

Fundamental

Principles
Independent

Variables
Dependent Variable

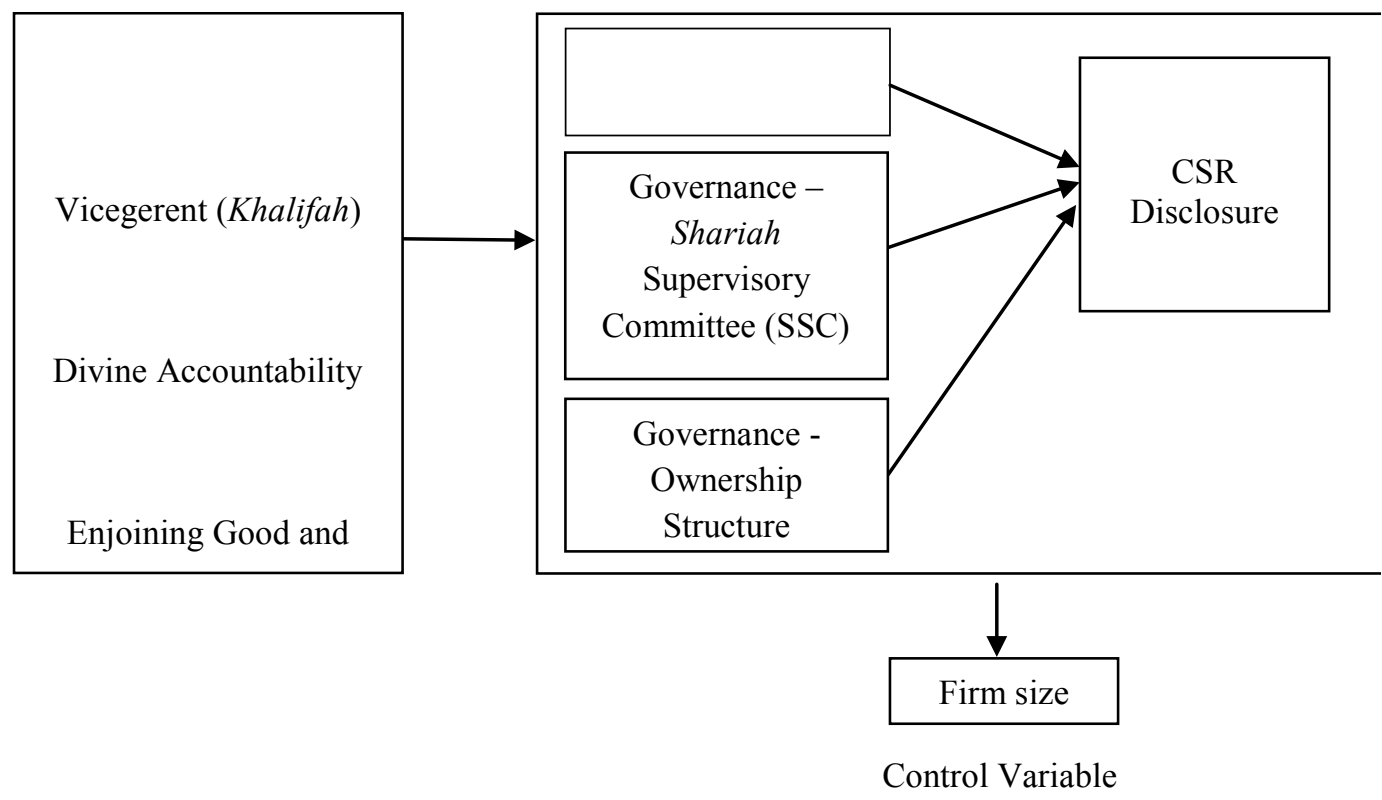

Figure 1: The Link of Shariah Fundamental Principles with the Independent

Variables and their Relationships with CSR Disclosure

Guided by prior studies, particularly Maali et al. (2003), Othman et al. (2009), and Farook et al. (2011), this study explores the CSRD of IFIs benchmarked against the Shariah fundamental principles and to subsequently ascertain the determinants of such disclosure. Specifically, this study seeks to examine whether the financial performance and governance (SSC and ownership structure) of the IFIs represent the primary determinants for their CSRD.

\section{Methodology}

IFIs are deemed as highly visible institutions in society as financial intermediaries with the primary objectives of providing financial resources and expertise as well as allocating funds to projects and other investments (Hassan and Harahap, 2010). Hence, IFIs can provide exemplary conduct aimed at achieving the overall objectives of being Shariah compliant on issues pertaining to allocating and redistributing justice. Based on the Bank Negara Malaysia (BNM) guidelines, IFIs refers to any Islamic bank licensed under the Islamic Banking Act
1983 (IBA), takaful and retakaful operators registered under the Takaful Act 1984 (TA), financial institutions licensed under the Banking and Financial Institutions Act 1989 (BAFIA) and that participate in the Islamic Banking Scheme, and the development financial institutions prescribed under the Development Financial Institutions Act 2002 (DFIA) that participate in the Islamic Banking Scheme. This study initially identified all 51 IFIs in Malaysia for sampling. However, 14 were excluded for reasons including the unavailability of annual reports on their respective websites and the incomplete CSR information in their annual reports. Finally, 37 IFIs were deemed fit to be enlisted for this study.

The CSR and other related information explored in this study were sourced from 2010 annual reports. The year 2010 was deemed relevant, in line with the introduction of AAOFI (2010) and the good representation of the development of the IFIs' CSR practice after the introduction of the CSR Framework by Bursa Malaysia in 2006. The annual reports were collected through 
the websites of Bank Negara Malaysia, Bursa Malaysia, and the IFIs. A CSRD index was developed based on the primary prevailing literature, including Othman et al. (2009), Bursa Malaysia (2007), Ousama and Fatima (2006), Sulaiman (2005), Haniffa (2002), and Baydoun and Willet (2000), Kazemian and Mohd-Sanusi (2015). The index was used to evaluate the variety of CSRD among the samples of this study. Forty-three items of disclosure were identified and further categorized into six themes, namely, finance and investment, products and services, employees, society, environment, and corporate governance (refer to Appendix A). These disclosure items were adopted from the studies listed above, on the basis of their relevance to Malaysian and Islamic business practices. A dichotomous coding method was applied for the disclosed CSR items (non-disclosure was coded as "0", CSRD as "1"). The nature of disclosures encompassed word(s), sentence(s), picture(s), or graphic(s) of activities/items relating to CSRD.

Table 2 summarizes the independent variables of this study and their related measurements.

Table 2: Summary of Independent Variables and their Measurement

\begin{tabular}{|c|c|c|c|}
\hline Hypothesis & & ndent Variables & Measurement \\
\hline \multicolumn{4}{|c|}{ Financial Performance - Return on Assets (ROA) } \\
\hline H1 & PROFIT & ROA & Employ ROA to measure financial performance \\
\hline \multicolumn{4}{|c|}{ Corporate Governance - Shariah Supervisory Committee (SSC) } \\
\hline \multirow[t]{8}{*}{$\mathrm{H} 2$} & IG-SCORE & Islamic governance score & $\begin{array}{l}\text { Existence of the SSC }+ \text { Number of SSC members }+ \text { Cross } \\
\text { memberships }+ \text { Doctorate qualification of SSC members }+ \\
\text { Reputable and experienced scholars on the SSC } \\
\text { (Derived from sub-variables below) }\end{array}$ \\
\hline & EXIST & Existence of SSC & 1 for Islamic banks with SSC; \\
\hline & & & 0 otherwise \\
\hline & NUM & Number of SSC & 1 for bank with three or more members ; \\
\hline & & members & 0 otherwise \\
\hline & CROSS & Cross memberships & $\begin{array}{l}1 \text { if any SSC member with cross-directorship (i.e., membership } \\
\text { in other IFIs); } 0 \text { otherwise }\end{array}$ \\
\hline & PHD & $\begin{array}{l}\text { Doctoral qualification of } \\
\text { SSC member }\end{array}$ & 1 if any SSC member has a doctorate; 0 otherwise \\
\hline & EXP & Experience of SSC member & $\begin{array}{l}1 \text { if any SSC member has working experience in the related } \\
\text { tasks; } \\
0 \text { otherwise }\end{array}$ \\
\hline \multicolumn{4}{|c|}{ Corporate Governance - Ownership Structure } \\
\hline $\mathrm{H} 3$ & IAH & Investment Account Holders & $\begin{array}{l}\text { Ratio of total amount of investment account funds to the paid- } \\
\text { up capital in the shareholders' equity }\end{array}$ \\
\hline \multicolumn{4}{|c|}{ Control Variable - Firm Size } \\
\hline & INSIZE & Size & Natural log of total assets by firm \\
\hline
\end{tabular}


Regarding the variable on the SSC, this study developed an Islamic governance score (IGSCORE) to measure the effect of governance on CSRD. The IG SCORE is constructed based on the existence and characteristics of the SSC embedded within the corporate structure among IFIs in Malaysia to ensure compliance with Shariah. The score represents the total value of the dichotomous characteristics of the committee, namely, the existence of the $\mathrm{SSC}$, the number of committee members, the occurrence of cross-memberships among committee members, the incidence of doctoral qualifications among committee members, and the inclusion of reputable scholars in the SSC.

Ordinary least square regression analysis was performed to test all the hypotheses. Analyses were performed to examine the relationship between CSRD and its determinants, specified as financial performance, SSC, and ownership structure. The regression equation model for the study is as follows:

CSRDIS $=a+\beta 1$ PROFIT + B2IG-SCORE + B3IAH + ß4INSIZE + e

Where

$\begin{array}{ll}\text { CSRDIS } & =\text { CSRD index score } \\ \text { PROFIT } & =\text { Return on Assets (ROA) } \\ \text { IG- } & =\text { EXIST+NUM+CROSS+PHD } \\ \text { SCORE } & + \text { EXP } \\ \text { IAH } & =\text { Ratio of Investment account } \\ & \text { holders' funds to paid up capital } \\ \text { INSIZE } & =\text { Natural log of IFIs's total assets } \\ \text { e } & =\text { Error term }\end{array}$

This regression model facilitated analysis for answering this study's three hypotheses. Thus, significant positive links are expected between financial performance (proxied by profit), SCC governance structure (proxied by IG-Score), ownership governance structure (proxied by
IAH), and the CSRD scores of the studied IFIs in Malaysia.

\section{Results and Discussion}

Table 3 summarizes the descriptive statistics for the IFIs' characteristics that were used as independent variables for this study. The overall mean value for ROA is 2.269543. Moreover, the value of ROA varied between a minimum -1.2794 to a maximum of 16.8119 .

Table 3: Descriptive Statistics for Independent Variables

\begin{tabular}{|l|c|c|c|c|c|}
\hline Variables & $\mathbf{N}$ & Min & Max & Mean & $\begin{array}{c}\text { Std. } \\
\text { Deviation }\end{array}$ \\
\hline ROA & 37 & -1.2794 & 16.8119 & 2.269543 & 3.4301358 \\
\hline IG-SCORE & 37 & 0 & 5 & 4.35 & 1.184 \\
\hline IAH & 37 & 0 & 158 & 14.07 & 27.709 \\
\hline
\end{tabular}

The mean value of SSC is considered reasonably high (mean score of 4.35), within a range between 0 and 5. All IFIs, except for two, established SSC within their corporate structure. These two IFIs, however, obtained advice on Shariah issues from the Shariah Advisory Council of BNM and other external entities which outsource their Shariah expertise. The variable of investment account holders (IAH) was measured using the ratio of investment account holders' funds (IAH, i.e., mudharabah) to the total paid-up capital, has been found to range from 0 to 157.98 with a mean value of 14.0659. This result suggests the existence of a sizeable gap for the IAH funds in which the possibility exists that some of the IFIs are yet to offer the mudharabah account facility to their investors and depositors.

Table 4 presents the descriptive statistics of information pertaining to CSRD of the IFIs studied from the four main segment related regulations. The IFIs under the DFIA 2002 attained the highest mean score for CSRD (a mean score of 26.16 or $60.83 \%$ of disclosure), hence indicating the presence of greater CSR awareness and concerns. The lowest mean 
Table 4: Descriptive Statistics of CSRD based on Segment of the IFIs

\begin{tabular}{|l|c|c|c|c|c|c|}
\hline Segments of IFIs & N & Minimum & Maximum & Mean & Std. Deviation & of CSRD \\
\hline IBA & 17 & 14.00 & 38.00 & 26.11 & 7.17533 & 60.72 \\
\hline BAFIA & 7 & 14.00 & 33.00 & 20.28 & 6.52468 & 47.16 \\
\hline DFIA & 6 & 18.00 & 38.00 & 26.16 & 8.15884 & 60.83 \\
\hline TA & 7 & 16.00 & 33.00 & 24.28 & 6.31702 & 56.46 \\
\hline
\end{tabular}

score for CSRD was obtained by IFIs under the BAFIA1989 (mean score 20.28or 47.16\% of disclosures). Diversity in the scores could be from the specialized nature of institutions established under the DFIA as a strategic conduit in bridging the gaps regarding the supply of financial products and services to key sectors of the economy, thereby resulting in their more proactive stance toward CSRD.

Below, Figure 2 illustrates the mean scores of CSRD according to six themes: finance and investment, products and services, employees, society, environment and corporate governance for IFIs in Malaysia for 2010 (see Appendix A for details of each item under the respective themes).
As shown in Figure 2, the total scores of the CSRD among the 37 IFIs studied suggest that with a score of 62 , societal CSR-related disclosures are the most disclosed information. Such outcome indicates that IFIs are undertaking CSR activities connected to their communities. These activities are consistent with Islamic values of CSR whereby, as khalifahs (vicegerents), IFIs bear the responsibilities of promoting the welfare of the society within which they exist and ensuring that socio-economic justice is upheld. Such obligations could be fulfilled through the practice of CSR activities which will then balance both the material and spiritual needs of society. Such acts are consistent with the objective of Shariah to promote the welfare of the people, by safeguarding their faith, life, intellect, posterity, and wealth (Al-Ghazali, 1937).

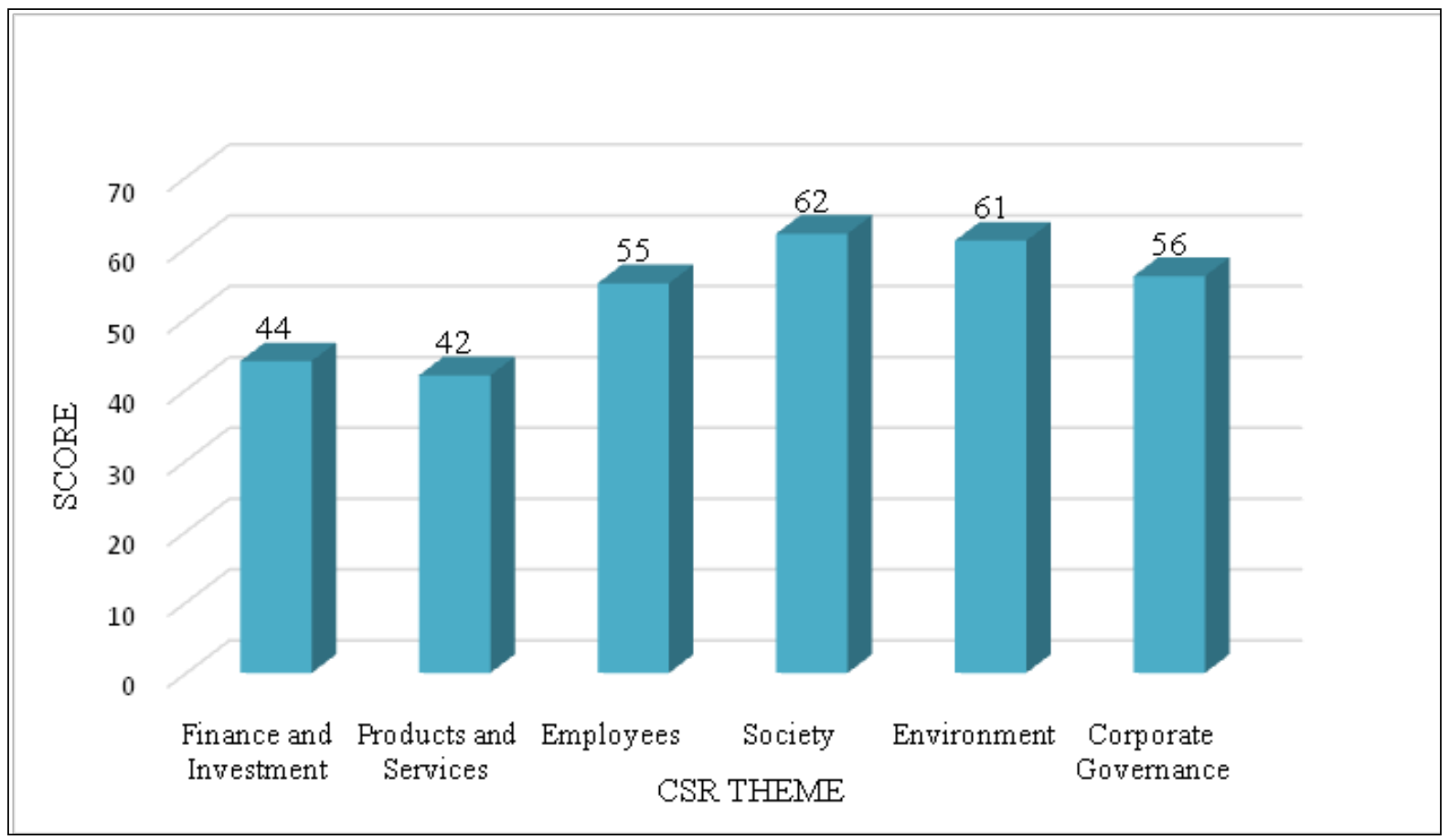

Figure 2: Total Scores of CSRD by Theme 
Interestingly, the second most disclosed CSR information among the IFIs relates to the environment, which emerged with a total score of 61 . This finding contradicts

prior literature which reveals minimal environmental disclosures among financial and non-financial institutions (e.g., Sumiani et al., 2007; Al Naimi et al., 2012; Yusoff et al., 2013; Joseph et al., 2016; Malin et al., 2014). As regards the implication of this finding, it highlights the pressing need to investigate the causes of the growing awareness and concern on environmental-related matters among the IFIs in Malaysia. To a certain extent, this study offers several preliminary ideas concerning IFI involvement in environmental activities, such as paperless business practices and overhead reduction through the usage of environmentally friendly equipment and machinery.

This research also found that the lowest theme disclosed involve products and services, earning a mean score of 42 . According to the CSR index utilized in this study, this finding implies that the IFIs are yet to embark on "green" or ecologically-friendly products. They also fail to reveal information regarding the halal status of their products, product safety and quality, customers' complaints, and non-compliance with regulations in their annual reports.

Based on the Pearson correlation, Table 5 presents the correlation coefficient values among the variables in this study. The values of correlation coefficients for all variables range between -0.033 and 0.377 . The dependent variable, i.e., the CSRD scores, has been found to have relationships with SSC and IAH, with " $r$ " "values of $0.293(\mathrm{p}$-value $=0.01)$, and 0.319 (p-value $=0.01)$, respectively. The variables financial performance (ROA) and size were statistically found to be significant at $1 \%$. Ownership structure (IAH) was also significant at the 0.05 level with the size of the IFIs (INSIZE) at 0.377.

\begin{tabular}{|c|c|c|c|c|c|}
\hline $\mathrm{N}=37$ & CSR & ROA & $\mathrm{SSC}$ & IAH & INSIZE \\
\hline CSR & 1 & 0.281 & $0.293 * *$ & $0.319^{* *}$ & -0.071 \\
\hline ROA & & 1 & 0.097 & -0.109 & $-0.450^{* *}$ \\
\hline $\begin{array}{l}\text { IG- } \\
\text { SCORE }\end{array}$ & & & 1 & 0.119 & -0.033 \\
\hline IAH & & & & 1 & $0.377^{*}$ \\
\hline INSIZE & & & & & 1 \\
\hline
\end{tabular}

Field (2009) claims that multicollinearity can be identified by analyzing the correlation matrix of variables and determining the high correlation among variables, when the value is greater than $0.8 / 0.9$. To identify the strength of relationship between two independent variables, the value should fall between -1.00 to 1.00 , where 1.00 represents the perfect positive correlation. Conversely, the relationship of variables can be ascertained by referring to $r=+/-0.10$ to 0.29 as a weak relationship, $r=+/-0.30$ to 0.49 as a moderate relationship, and $\mathrm{r}=+/-0.50$ to 1.00 as a strong relationship. Table 5 represents the Pearson correlation coefficient product moment (bivariate) of both dependent and independent variables. In this study, multicollinearity does not exist as proven by the $r$ value being less than 0.8 . The results of the study as shown in Table 5 also indicate that there was no multicollinearity problem among the variables since none of the correlation coefficients exceeded 0.8 . Consequently, further analysis was made possible.

In relation to the hypotheses $(\mathrm{H} 1, \mathrm{H} 2$, and $\mathrm{H} 3)$, Table 6 presents the regression analyses on the relationship between the independent variables and the CSRD among the IFIs in Malaysia. The multiple $\mathrm{R}$ (i.e., $\mathrm{R}=0.506$ ) indicates a substantial correlation between the independent variables and the dependent variable, suggesting that the linear regression predicted highly satisfactory results. The adjusted $\mathrm{R}^{2}$ of $16.3 \%$ implies the existence of other potential determinants that 
Table 6: Regression Analysis Model

\begin{tabular}{|c|c|c|c|c|c|c|}
\hline \multirow[t]{2}{*}{ Model } & & \multicolumn{2}{|c|}{ Unstandardized Coefficients } & \multirow{2}{*}{$\begin{array}{c}\text { Standardized } \\
\text { Coefficients }\end{array}$} & \multirow[t]{2}{*}{$\mathbf{T}$} & \multirow[t]{2}{*}{ Sig. } \\
\hline & & B & Std. Error & & & \\
\hline (Constant) & & 22.277 & 15.224 & & 1.463 & .153 \\
\hline ROA & & .547 & .358 & .263 & 1.528 & .136 \\
\hline IG-SCORE & & 1.350 & .933 & .224 & 1.446 & $.108 *$ \\
\hline IAH & & .090 & .043 & .350 & 2.099 & $.044 * *$ \\
\hline SIZE & & -.271 & .651 & -.077 & -.417 & .680 \\
\hline Sig.(ANOVA) & $=0.045$ & & & & & \\
\hline $\mathrm{R}$ & $=0.506$ & & & & & \\
\hline $\mathrm{R}^{2}$ & $=0.256$ & & & & & \\
\hline Adjusted $\mathrm{R}^{2}$ & $=0.163$ & & & & & \\
\hline F-statistic & $=2.753$ & & & & & \\
\hline
\end{tabular}

may affect the disclosure of CSR information among the IFIs in Malaysia.

Hypothesis 1 predicts a positive relationship between financial performance (ROA) and CSRD among the IFIs in Malaysia. As the findings failed to support this hypothesis, H1 is therefore rejected. Nevertheless, this outcome is consistent with Hackston and Milne (1996) and Mohamed Zain (1999), who argue that financial performance is not entirely related to CSRD. Masruki et al. (2010) also state that the overall purpose and existence of an IFI is linked to fulfilling socio-economic related objectives, including the creation of a just society instead of masquerading as another profit-driven entity. Thus, financial performance, as measured by bottom line ROA, should not be regarded as the predominant benchmark for the IFIs to undertake CSR activities.

Hypothesis 2 predicts a positive relationship between IG-SCORE and CSRD among the studied IFIs. As the results signify a positive significant relationship (significant at 10\% level, $\mathrm{p}$-value $=0.108)$, therefore $\mathrm{H} 2$ is accepted. Such findings are consistent with those of Zighaba (2009), Garas and Pierce (2010), and Farook et al. (2011), who discover a positive link between governance and CSRD through the establishment of a Shariah supervisory committee. Consequently, this link generates the belief which interlineated the guidance and advice IFIs received from their respective SSCs to not only offer Shariah compliant products and services, but to also to undertake CSR-related activities in accordance with an Islamic ethical business framework. Essentially, being socialoriented organizations, IFIs are deemed to be extremely socially responsible and to operate within a more transparent business environment, in accordance with Shariah principles.

Table 7: Summary of the Results of the Multiple Regression Analysis

\begin{tabular}{|l|l|l|}
\hline Hypothesis & $\begin{array}{l}\text { Predicted } \\
\text { sign }\end{array}$ & Result \\
\hline $\begin{array}{l}\text { H1: A positive relationship exists } \\
\text { between financial performance and } \\
\text { CSRD }\end{array}$ & +ve & Rejected \\
\hline $\begin{array}{l}\text { H2: A positive relationship exists } \\
\text { between the SSC and CSRD }\end{array}$ & + ve & Supported \\
\hline $\begin{array}{l}\text { H3: A positive association exists } \\
\text { between ownership structure and } \\
\text { CSRD. }\end{array}$ & + ve & Supported \\
\hline
\end{tabular}

Hypothesis 3 predicts a positive relationship between the IAH and CSRD. The results in Table 6 indicate that IAH is significant (at 5\% level, p-value $=0.044)$. Hence, H3 is accepted. This outcome is consistent with that of Farook et al. (2011) who find a positive relationship between IAH (used as a proxy for ownership structure) and CSRD (Ghazali, 2007; Othman et al., 2009). 


\section{Conclusion}

This study examined the current CSRD and factors that influenced the degree of disclosure among IFIs in Malaysia. As IFIs are established with the primary objective of conducting business activities according to Shariah principles, by the same token they are expected to be accountable and transparent in providing information. Such expectations encompass the variety of their products and services for customers and the revelations of their CSR activities.

In light of the findings of this study, five significant implications can be made. First, the IFIs under the DFIA 2002 scored the highest mean score for CSRD. Second, the concern shown with respect to the societal and environmental themes is consistent with the underlying philosophy of Islam, wherein IFIs, in their representation as khalifah, are expected to fulfill their duties holistically, i.e., to improve the quality of life of society at large and care for the natural environment. Third, the results also suggest that strengthening the corporate governance framework of IFIs through embedding SSC within the corporate structure would not only guarantee the production of Shariah-compliant products and services but also facilitate greater transparency and accountability of CSRD within an Islamic business framework. Fourth, the outcomes also provide evidence that Islamic investors are capable of influencing IFIs in undertaking CSR activities. This particular finding supports the notion that CSRD functions as a strategic mechanism in authenticating the reputation of IFIs as "authentic" Islamic financial institutions. Finally, the outcomes also revealed that profitability is not the predominant influence for CSRD. Cumulatively, these findings support the fundamental principle of Islam whereby CSR activities should not be dependent upon the profitability of an organization but should be undertaken as part of its on-going social responsibility to care for the well-being of society and to guarantee environmental sustainability well into the next generation. Overall, the results of this research offer a foundation for a comprehensive Islamicbased CSR reporting framework in the future.

\section{Future Research Directions}

Given the limited scope and depth of this study, future studies on the determinants of CSRD by IFIs should be undertaken, albeit from differing perspectives. Using larger samples from leading Malaysian-based IFIs or expanding the geographical dimension to include IFIs from within the South-East Asian or even ASEAN regions would be enlightening academic explorations.

We also assert that another subset of data from other sources, such as the print media (e.g., newspapers and corporate bulletins), electronic media (e.g., television and radio), and the Internet (e.g., company website) would offer many new opportunities for understanding the motivation behind CSRD. Using such options would ensure that future studies benefit from a myriad of data sources and a wider perspective.

The beneficiaries of these potential studies would be the IFIs themselves, as they would further enhance their legitimacy as true flagbearers of the Islamic financial community. In this regard, the relevant regulatory bodies and government agencies will also benefit vis-àvis the formulation of Islamic-based CSRD reporting guidelines/frameworks.

\section{References}

AAOIFI (2010). Corporate Social Responsibility Conduct and Disclosure for Islamic Financial Institution. Accounting and Auditing Organization for Islamic Financial Institutions, Manama, Bahrain.

Abdul Azeez, Y. (2012). Perspective from Shariah on Legal and Human Rights. Global Journal Al-Thaqafah, 2(2): 17-25. 
Al-Ghazali, A. H. M. (1356/1937). Al-Mustasfa min 'Ilm al-Usul. Vol. 1, Cairo: Al-Maktabah Al-Tijariyyah.

AlNaimi, H.A., Hossain, M. \& Momin, M.A. (2012). Corporate Social Responsibility Reporting In Qatar: A Descriptive Analysis. Social Responsibility Journal, 8(4): 511-526.

Archer, S., Karim, R. A. A. \& Deehani, T. A. (1998). Financial Contracting, Governance Structures and The Accounting Regulation of Islamic Banks: An Analysis in Terms of Agency Theory and Transaction Cost Economics. Journal of Management and Governance, 2: 149-170.

Aribi, Z. A. \& Gao, S. (2010). Corporate Social Responsibility Disclosure: A Comparison between Islamic and Conventional Financial Institutions. Journal of Financial Reporting and Accounting, 8(2): 72-91.

Baydoun, N. \& Willett, R. (1997). Islam Ethical Issues in the Presentation of Financial Information. Accounting, Commerce \& Finance. The Islamic Perspective Journal, 1(1): 1-25.

Belkaoui, A. \& Karpik, P. G. (1989). Determinants of the Corporate Decision to Disclose Social Information. Accounting, Auditing \& Accountability Journal, 2(1): 36-51.

Bourgeois, L. J. (1981). On the Measurement of Organizational Slack. Academy of Management Review, 6: 29-39.

Buchholtz A. K., Amason A. C. \& Rutherford M. A. (1999). Beyond Resources: The Mediating Effect of Top Management Discretion and Values on Corporate Philanthropy. Business Society, 38(2): 167-187.

Bursa Malaysia (2007). The Islamic Capital Market. Kuala Lumpur: Bursa Malaysia. Available at: http://www.bursamalaysia.com (accessed 23 November 2015).
Darus, F., Yusoff, H., Abang Naim, D. M., Mohamed Zain, M., Amran, A., Fauzi, H. \& Purwanto, Y. (2013). Islamic Corporate Social Responsibilities (i-CSR) Framework for Islamic Banks: Application of Maqasid Al-Shariah and Maslahah Principles. Issues in Social and Environmental Accounting (ISEA), 7(2): 102112.

Elasrag, H. (2014). Corporate Governance in Islamic Financial Institutions. CreateSpace Independent Publishing Platform.

El-Gazzar, S. M. (1998). Pre-disclosure Information and Institutional Ownership: A Cross-Sectional Examination of Market Revaluations during Earnings Announcement Periods. The Accounting Review, 7(1): 119-29.

Eng, L. L. \& Mak, Y. T. (2003). Corporate Governance and Voluntary Disclosure. Journal of Accounting \& Public Policy, 22(4): 325-345.

Farook, S. (2007). On Corporate Social Responsibility of Islamic Financial Institutions. Islamic Economies Studies, 15(1): 31-46.

Farook, S., Hassan, M. K. \& Lanis, R. (2011). Determinants of Corporate Social Responsibility Disclosure: The Case of Islamic Banks. Journal of Islamic Accounting and Business Research, 2(2): $114-141$.

Fauzi, H. \& Idris, K. M. (2009). The Relationship of CSR and Financial Performance: New Evidence from Indonesia Companies. Issues in Social and Environment Accounting, 3(1): 66-87.

Fauzi, H., Mahoney, S. L. \& Abdul Rahman, A. (2007). The Link Between Corporate Social Performance and Financial Performance: Evidence from Indonesian Companies. Issues in Social and Environmental Accounting, 1(1), 149-159. 
Field, A. (2009). Discovering Statistics Using IBM SPSS Statistics. London: Sage Publications Ltd.

Garas, S. N. \& Pierce, C. (2010). The Independence of the Shari'a Supervisory Board in the Islamic Financial Institutions of the GCC Countries. The First Annual Online International Conference on Corporate Governance \& Regulation in Banks, Sumy, Ukraine.

Ghani, E., \& Said, J. (2010). Digital Reporting Practices Among Malaysian Local Authorities. Electronic Journal of e-Government, 8(1), 3345.

Ghazali, N. A. M. (2007). Ownership Structure and Corporate Social Responsibility Disclosure: Some Malaysian Evidence. Corporate Governance, 7(3): 251-266.

Gompers, P., Ishii, J. \& Metrick, A. (2001). Corporate Governance and Stock Prices. NBER Working Paper No. 8449, National Bureau of Economic Research, Cambridge, MA.

Hackston, D. \& Milne, M. J. (1996). Some Determinants of Social and Environmental Disclosure in New Zealand Companies. Accounting, Auditing and Accountability, 18: 77-108.

Hameed, S., (2009). Accounting and Auditing for Islamic Financial Institutions. IIUM Press, Kuala Lumpur.

Haniffa, R., (2002). Social Reporting Disclosure: An Islamic Perspective. Indonesian Management \& Accounting Research, 1(2): 128-146.

Hassan, A. \& Harahap, S. S. (2010). Exploring Corporate Social Responsibility Disclosure: The Case of Islamic Banks. International Journal of Islamic and Middle Eastern Finance and Management, 3(3): 203-227.
Ho, S. S. M. \& Wong, K. S. (2001). A Study of the Relationship between Corporate Governance Structures and the Extent of Voluntary Disclosure. Journal of International Accounting, Auditing \& Taxation, 10: 139-56.

Janggu, T., (2004). Corporate Social Disclosure of Construction Companies in Malaysia. Master Thesis, Universiti Teknologi MARA.

Jensen, M. C. \& Meckling, W. H. (1976). Theory of the Firm: Managerial Behaviour, Agency Costs and Ownership Structure. Journal of Financial Economics, 3: 305-360.

Joseph, C., Gunawan, J., Sawani, Y., Rahmat, M., Noyem, J. A., \& Darus, F. (2016). A comparative study of anti-corruption practice disclosure among Malaysian and Indonesian Corporate Social Responsibility (CSR) best practice companies. Journal of Cleaner Production, 112, 2896-2906.

Kamla, R., Gallhofer, S. \& Haslam, J. (2006). Islam, Nature and Accounting: Islamic Principles and the Notion of Accounting for the Environment. Accounting Forum, 245-265.

Karim, R. A. A. (1995). The Nature and Rationale of a Conceptual Framework for Financial Reporting by Islamic Banks. Accounting and Business Research, 25(100): 285-300.

Kazemian, S., \& Sanusi, Z. M. (2015). Earnings Management and Ownership Structure. Procedia Economics and Finance, 31, 618-624.

Khurshid, M. A., Al-Ali, A., Soliman, A. A. \& Amin, S. M. (2014). Developing an Islamic Corporate Social Responsibility Model (ICSR). Competitiveness Review, 24(4): 258-274.

Lee, J. \& Menon, A. (2010). Islamic Finance - The Year that was and the Outlook for 2010", available at: http://rd.kpmg.co.uk/ WhatWeDo/20939.htm. (accessed 5 May 2015). 
Lungu, C. I., Caraiani, C. \& Dascalu, C., (2011). Research on Corporate Social Responsibility Reporting. Amfiteatru Economic, XIII(29): 117-131.

Maali, B., Casson, P. \& Napier, C. (2003). Social Reporting by Islamic Banks. Discussion Paper in Accounting and Finance (University of Southampton, Southampton), 1-39.

Malin, C., Farag, H. \& Ow-Yong, K. (2014). Corporate Social Responsibility and Financial Performance in Islamic Banks. Journal of Economic Behavior \& Organization, 103: 108128.

Masruki, R., Ibrahim, N. \& Azizan, N. A. (2010). Incorporating Corporate Social Responsibility into Sustainable Financial Performance of Islamic Banks in Malaysia", $2^{\text {nd }}$ Conference on Islamic Finance and Economics International, LIFE2010. Langkawi.

Mitchell, J.D., Chia, C.W.L \& Loh, A.S. (1995). Voluntary Disclosure of Segment Information: Further Australian Evidence. Accounting and Finance, 35(2): 1-16.

Mohamed Zain, M. (1999). Corporate Social Reporting in Malaysia: The Current State of the Art and Future Prospects. Dissertation for the Degree of Doctor of Philosophy, University of Sheffield.

Mosaid, F. E. \& Bouttii, R. (2012). Relationship between Corporate Social Responsibility and Financial Performance in Islamic Banking. Research Journal of Finance Accounting, 3(10): 93-103.

Muwazir, M. R., Muhamad, R. \& Noordin, K. (2006). Corporate Social Responsibility Disclosure: A Tawhidic Approach. Jurnal Shariah, 14(2): 12-142.
Nor, S. M. \& Hashim, N. A. (2014). CSR and Sustainability Dimension in Islamic Banking in Malaysia: A Management Insight. Proceedings of 26th International Business Research Conference 7 - 8 April 2014, Imperial College, London, UK.

Othman, R., Thani, A. M. \& Ghani, E. K. (2009). Determinants of Islamic Social Reporting Among Top Shariah-Approved Companies in Bursa Malaysia. Research Journal of Internatıonal Studies, 12(10):1-17.

Ousama, A.A. \& Fatima, A. H. (2010). Voluntary Disclosure by Shariah Approved Companies: An Exploratory Study. Journal of Financial Reporting and Accounting, 8(1): 35-49.

Paino, H., Bahari, A., Anis, B. \& Abu Bakar, R. (2111). Shariah, Social Responsibilities and Corporate Governance of the Islamic Banks in Malaysia. European Journal of Social Sciences, 23(3): 382-391.

Said, J. (2010). The Mediating Effects of Organizational Learning Orientation on the Relationship between Strategic Management Accounting Information Use and Organizational Performance. Asia-Pacific Management Accounting Journal, 5(2), 11-29.

Said, R., Zainuddin, Y. \& Haron. H. (2009). The Relationship between Corporate Social Responsibility Disclosure and Corporate Governance Characteristics in Malaysian Public Listed Companies. Social Responsibility Journal, 5(2): $212-226$.

Schadewitz, H. J. \& Blevins, D. R. (1998). Major Determinants of Interim Disclosure in an Emerging Market. American Business Review, 16(1): 41-55. 
Siregar, S. V. \& Bachtiar, Y. (2010). Corporate Social Reporting: Empirical Evidence from Indonesian Stock Exchange. International Journal of Islamic and Middle Eastern Finance and Management, 3(3): 241-251.

Sulaiman, M. (2005). Islamic Corporate Reporting: Between the Desirable and the Desired. Research Centre, IIUM Publication.

Sumiani, Y., Haslinda, Y. \& Glen, L. (2007). Environmental in Developing Country: A Case Study on Status and Implication of Environmental Reporting. Journal of Cleaner Production, 15(10): 895-901.

Tsoutsoura, M. (2004). Corporate Social Responsibility and Financial Performance. Working paper series, Centre for Responsible Business, UC Berkeley.

Waddock, S. A. and Graves, S. V. (1997). The Corporate Social Performance-Financial Performance Link. Strategic Management Journal, 18(4): 303-319.
Widana, G. N. O., Wiryono, S. K., Purwanegara, M. S \& Toha (2014). Measuring Islamic Business Ethics within Indonesia Islamic Banks. Global Journal Al-Thaqafah, 4(2): 5-15.

Yusoff, H., Darus, F., Fauzi H. \& Purwanto, Y. (2013). Exploring the Environmental Reporting Practices of Islamic Banks: A Case of Malaysia and Indonesia. Journal of Energy Technologies and Policy-Special Issues for International Conference on Energy, Environment and Sustainable Economy (EESE 2013), 3(11): 440-445.

Yusuf, M. M. \& Basah, M. Y. A. (2013). Islamic Bank and Corporate Social Responsibility (CSR). EJBM-Special Issue: Islamic Management and Business, 5(11): 194-209.

Zighaba, E. (2009). The Boards of Fatwa and Shari'a Supervision in Islamic Financial Institutions: Their Importance, Restrictions, and Recommended Solutions. Proceedings of the Conference of Islamic Banking between Reality and Expectations, Dubai, UAE, 1-3. 